\title{
Spiritual and ethical transformational leadership: Critical discourse analysis within a practical theology praxis
}

\begin{abstract}
Author:
Gordon E. Dames ${ }^{1}$

Affiliation:

${ }^{1}$ Department of Philosophy, Practical and Systematic

Theology, University of South Africa, South Africa

Correspondence to:

Gordon Dames

Email:

damesge@unisa.ac.za

Postal address:

PO Box 392, Pretoria 0003, South Africa

Dates:

Received: 27 May 2013

Accepted: 19 Nov. 2013

Published: 13 June 2014

How to cite this article: Dames, G.E., 2014, 'Spiritual and ethical transformational leadership: Critical discourse analysis within a practical theology praxis', Koers Bulletin for Christian Scholarship 79(2), Art. \#2116, 8 pages. http:// dx.doi.org/10.4102/koers. v79i2.2116

\section{Note:}

This article was presented as a paper to the Colloquia 2011-2015 University of South Africa (UNISA) and Rice University Conference, with the theme: Religious, ethical and theological voice and voicelessness: Religious, ethical, political and theological prespectives on social discourse and praxis in the new millennium on 06 October 2011. In addition, it is based on a paper presented at the Christian Leadership Conference, held at UNISA on 21-22 February 2013.
\end{abstract}

\section{Read online:}

Scan this QR code with your smart phone or mobile device to read online.
The objective of this article is to focus renewed attention on ethics in contemporary dialogue through value-based leadership. This is done with reference to the value of meaning in social research and critical discourse analysis within a framework of leadership discourse praxis. Discourse constructs, such as dominance and power, are analysed in the (re)production of oppression, injustice and inequality. The objective is to analyse the way in which human ideas and the actions of powerful and dominant leadership elites are influencing and dominating ethical and / or unethical public enactments. The hypothesis is that ethical discourse enactments (practices) could foster authentic ethical and transformational leadership.

Spirituele en etiese transformasionele leierskap: Kritiese diskoersanalise binne 'n praktiese teologie praxis. Hierdie artikel poog om hernude fokus te plaas op etiek in kontemporêre dialoog in terme van waardegebaseerde leierskap. Derhalwe word die waarde van betekenis in sosiale navorsing en kritiese diskoers analise binne die raamwerk van 'n leierskapsdiskoerspraxis bestudeer. Diskoers konsepte, onder andere oorheersing en mag, word geanaliseer in die lig van die (her)produksie van onderdrukking, ongeregtigheid en ongelykheid. Die mate waartoe alledaagse idees en handelinge van die magtige en dominante leierskap elite etiese en/of onetiese publieke interaksie beïnvloed en oorheers, word geanaliseer. Die hipotese is dat etiese diskoershandelinge (praktyke) ware en/of betroubare etiese en transformatiewe leierskap kan bevorder.

\section{Introduction}

Critical forms of research call current ideology into question, and initiate action in the cause of social justice. In the type of enquiry spawned by a critical spirit, researchers find themselves interrogating commonly held values and assumptions, challenging conventional social structures and engaging in social action. Fuelling this enterprise is an abiding concern with issues of power and oppression (Crotty 2005:157).

In the 21st century we have seen a shift in leadership styles from transaction-based to more valuebased leadership, such as servant, spiritual and transformational leadership. This trend is seen as being counteractive to hegemonic practices (Strock 2010:7). In addition, critical thought and analysis are instrumental in analysing the power of ideas and actions in leadership discourse praxes (Crotty 2005:157; Van Dijk 1993).

\section{Rationale and outline}

New leadership perspectives can help us to address negative leadership praxes through communication or discourse on countering hegemonic practices through discourse ethics. The thesis of this article is that value-based leadership through ethical discourse fosters authentic relationships to transform hegemonic leadership practices. First, this is done by constructing a theoretical leadership framework of value-based leadership. Secondly, a new way of practical leadership discourse praxis is proposed by which the voicelessness of the 'other' ${ }^{1}$ is redressed through communicative and discourse ethics. Thirdly, an ethical discourse methodology is described within the framework of the culture of silence and the public mind. Fourthly, and finally, a practical theological leadership praxis framework is proposed, followed by the conclusion.

\section{Theoretical leadership framework}

Whilst the quest for ethical leadership, or as Snyder and Lopez (2002:829) convincingly argue, the strengths for leaders to deal effectively with life in a postmodern society, is becoming more 1.The 'other' in this article refers to the followers of leaders, oppressed people and minority groups with limited access to political, social, cultural and economic power.

Copyright: (C) 2014. The Authors. Licensee: AOSIS OpenJournals. This work is licensed under the Creative Commons Attribution License. 
prevalent and relentless, a powerful anti-leadership culture is also emerging in response to multiple public failures of leaders (Dames 2008b). These leaders abuse their authority in almost every sector of society, be it political, business, labour, civil, and even religious (Wallis 2004:9). Leadership is crucial for transformation and value-based leadership models provide a framework for ethical leadership discourse in communities (Van Eeden, Cilliers \& Van Deventer 2008:253). The types of leadership style that undergird value-based, spiritual and transformational leadership traits are essential for a theoretical leadership framework to address negative leadership praxes today. The following paragraphs deal with the meaning and role of these leadership traits to address contemporary challenges.

\section{Spiritual leadership}

A new language of leadership today is characterised by the prominence of value-based leadership (Crossman 2010; Mandela 1995; Rensburg 2002; Russel 2001). Value-based leadership is an inclusive term referring to leadership traits such as ethical, spiritual, servant and transformational leadership. McSherry and Cash (in Gall, Mallette \& GuirguisYounger 2011:159), for instance, attempt to address the complexity of spirituality through their proposed 'spiritual taxonomy'. Spiritual taxonomy dissolves the bipolar tension between the transcendental and humanistic existential praxes that focus on meaning and purpose in life (Gall et al. 2011:159). Spirituality has thus become a new challenge for 21st century scholars in terms of which theoretical frameworks and methodologies for leadership have to be developed (Giacalone \& Jurkiewicz 2003:4; GranbergMichaelson 2004; Wallis 2004:9). ${ }^{2}$ The need for spirituality has resulted from a growing diminished view of leadership identity that exacerbates feelings of social alienation and fear (Dames 2008a, 2008b). Twenty-first century leaders are thus compelled to search for deeper meaning or postmaterialist assets in life and work (Ali \& Falcone 1995, cited in Giacalone \& Jurkiewicz 2003:3). Giacalone and Jurkiewicz (2003:13) define leadership spirituality in terms of values, experiences of transcendence, ontology and wellness. The same should be applicable to ethical, servant and transformational leadership.

It is crucial that 21st century leaders create climates of trust by identifying values, building integrity and sustaining vision (Granberg-Michaelson 2004:31). Servant leaders are best positioned to lead spiritually-rich leadership responsibilities in transforming negative perceptions of leadership (Kolodinsky, Bowen \& Ferris 2003:169). Servant leadership correlates with the principles of transformational leadership (Kolodinsky et al. 2003:170). The promotion of spirituality has become crucial in contemporary social scenarios filled with uncertainty and potentially untrustworthy workers, leaders and followers. The creation of ethical climates is therefore necessary in the development of leadership spirituality

2.Spiritual concerns are not synonymous with religious ones; spiritual concerns are separate from participation in and the sharing of beliefs with any particular religious groups (Veach \& Chappell 1991, cited in Giacalone \& Jurkiewicz 2003:5).
(Parboteeah \& Cullen 2003:149-150). ${ }^{3}$ This is only possible through the transformation of oppressive hierarchical praxes (Rowan 2001:154). Leaders are spiritual beings in a spiritual universe, seeking meaning within their respective spiritual worlds of work. 'The concept of a spiritual leader stresses the moral centre of the leader' (Doohan 2007:17). The spiritual leader's vision, mission, goals, objectives and strategies are analysed in terms of the internal competency of moral commitment (Doohan 2007:17). Spirituality is a source of motivation and inspiration in creating morally sound decisions and actions based on ultimate values (Hess \& Cameron 2006:75). It is also a hermeneutical framework or lens through which leaders perceive, communicate and act in and with the world, themselves and others (Gall et al. 2011:166). This calls for transformative changes in the fundamental nature of leadership to communicate and act morally and authentically. A new kind of vision and mission for leadership are sought (Rowan 2001:158). Servant ethical leadership, for example, engenders principles of spirituality, transactional, laissez-faire, transformational leadership and ethical communication (Bass 1985; Burns 1978 cited in Kolodinsky et al. 2003:170). This brings us to the question: How can ethical transformational leadership deal with negative leadership praxes?

\section{Ethical transformational leadership}

Transformational leadership is not only a necessity, but a prerequisite in the post-industrial world of work and the post-institutionalised world of leadership (Cascio 1995:930, cited in Bass \& Steidlmeier 1999; Roxburgh 2005). Dobbs (2010:10) illuminates postmodern leaders' transformational role with five skills, namely, building a culture; improving esprit de corps [morale - spirit of a group as a single body]; communicating issues and actions; changing the financial results; and developing a cadre of future transformational leaders (Dobbs 2010:10). Transformational leadership engenders higher levels of motivation and morality between leaders and the 'other' (Burns 1978:20, cited in Kolodinsky et al. 2003:170). ${ }^{4}$ Suffice it to state that leadership discourse praxes that abandon existential responsibility for selfinterest pose a threat to society and call for the quest of ethical transformational leadership (Bass \& Steidlmeier 1999). In the light of what Price (2003:67) defines as 'worries about the morality of transformational leadership', this becomes even more important. The distinction between the culture of authentic transformational leadership and inauthentic or pseudo-transformational leadership is crucial (Bass \& Steidlmeier 1999). Cultural changes in leadership praxes are critical in shifting personal power bases and empowering others (Giacalone \& Jurkiewicz 2003:11; Keifert 2006). Leadership should apply spiritual-based cultural

3.'Ethical climates are a subset of the more general array of work climates. The ethical climate construct delineates a group of prescriptive climates reflecting prevailing organizational practices with moral consequences. Ethical climates help workers solve ethical issues by giving them answers to "what should I do?" when faced with a moral dilemma (Homans 1950). In addition, ethical climates also help employees a moral dilemma (Homans 1950 ). In addition, ethical climates also help employees identify ethical issues within the organisation. In other words, ethical climates serve
as a perceptual lens through which workers diagnose and assess situations' (see Parboteeah \& Cullen 2003:138).

4.'The four dimensions of transformational leadership - individualized consideration, idealized influence, inspirational motivation, and intellectual stimulation (Bass \& Avolia 1994)' become crucial elements in fostering workplace or leadership equilibrium (Kolodinsky et al. 2003:170). 
transformation in order to shift power relationships. This may be done by fostering change through an intentional and persistent process of formulating a vision, a mission and values (Granberg-Michaelson 2004:109; Keifert 2006). Leaders need to build ethical communities of discourse for the common good by empowering and serving the 'other' (Granberg-Michaelson 2004:131). This brings us to the question of how leadership should foster the common good for communities without imposing egocentric self-interests and questionable altruistic values.

\section{Challenges facing authentic ethical transformation leadership}

An ethical critique of authentic transformational leadership is, therefore, crucial (Price 2003:67; Bass \& Steidlmeier 1999). Price (2003:67) holds the view that the distinction between authentic transformational leadership and pseudotransformational leadership does not provide an acceptable response to ethical concerns about transformational leadership. Even altruism, in certain instances, and particularly blinded egocentric values engender leaders' self-justification of immoral behaviour as authentic (Price 2003:67). ${ }^{5}$ Owing to the fact that ethical failures can be viewed essentially as volitional and not as cognitive, leaders behave unethically because of problems of will, not because of problems of belief and knowledge (Price 2003:69). The fact that leaders have epistemic access to what is morally required of them, does not guarantee that they will not be guided by self-interest and even demands of the 'other', which may lead to immoral actions (Granberg-Michaelson 2004:51).

Price (2003:69) consequently criticises the altruistic assumption about the ethics of transformational leadership. Specifically so when a leader's self-interest competes with what they generally know they morally ought to do. ${ }^{6}$ Leaders sometimes presume and maintain that they are somehow exempted from moral obligations that apply more generally to the rest of their followers. Transformational leaders may even justify themselves in violating these prohibitions for the sake of other-regarding values - dictated by their followers (Price 2003:69). This brings us to the question how a valueoriented culture of leadership should be developed.

\section{A value-based leadership culture}

Values are crucial in shaping a sound leadership culture. Values can guide and defend leaders' behaviour and actions in new and unfamiliar territory whilst upholding and strengthening their inherent values (Granberg-

5.1 argue that the distinction between authentic transformational leadership and pseudo-transformational leadership fails to ground a sufficient response to ethical concerns about transformational leadership. To the extent that this theory holds that altruism suffices for ethical success, it misses the fact that leaders sometime behave immorally precisely because they are blinded by their own values. In the end, we can expect that this kind of blindness will come to bear importantly on the moral psychology of leadership and, in some cases, encourage transformationa leaders to believe that they are justified in making exceptions of themselves on the grounds that their leadership behaviour is authentic' (Price 2003:69).

6.Bass and Steidlmeier (1999:191, cited in Price 2003:70) state that 'the exclusive pursuit of self-interest is found wanting by most ethicists'. Price (2003:69) challenges the altruism of transformational leaders in instances where they disregard general the altruism of transformational leaders in instances where they disregard general
moral principles in order to serve the demands or questionable values of their followers.
Michaelson 2004:116). Doohan (2007:38-43) identifies certain values for leaders, namely, dedicated to service; honest vulnerability; inner integrity; commitment to example; coaching and guiding participation; creating a climate of mutual trust; influencing others to be visionaries; fostering self-leadership in followers; reliability in moments of truth; inspiring commitment to the shared vision; showing love and encouragement; caring for followers; criticising constructively; bearing the pain; and generating enthusiasm (cf. Russel \& Stone 2002). It is therefore paramount that authentic ethical transformational leadership should be the embodiment of value-congruent agents in fostering ethical discourse praxes (Bass \& Steidlmeier 1999). Pseudotransformational leaders, however, seek value-congruence by sharing unrealistic, unattainable and exploitative expectations. The latter practice should be transformed by sound leadership. For instance, transformational leadership and congruent followers are value-centred, consequently sharing visions and values, mutual trust and respect, and unity in diversity (Giacalone \& Jurkiewicz 2003:3). We need to focus in the next paragraph on the question: How should leaders should develop the abovementioned principles in terms of their followers?

\section{Value congruence between leaders and the other's discourse}

The role of transformational leaders is to facilitate the process of forging common ground with the 'other'. Transformational leaders raise followers' aspirations and activate their higher order values. They also facilitate followers to identify with leaders or their mission (Avolio, Walumbwa \& Weber 2009:249; Yukl 2006:273). Hermeneutical dialectic leadership communication is instrumental in this regard because it fosters altruistic values and cooperative decision making (Kolodinsky et al. 2003:170). ${ }^{7}$ Discourse ethics is therefore, crucial because it fosters interpersonal and intrarelational interactions and engages in a complex set of processes through primary moral formative leadership praxes (Granberg-Michaelson 2004:48). It helps to build relationships of trust and respect to establish shared values and mutual cooperation.

Value-based leadership engenders 'a moral foundation of legitimate values' (Bass \& Steidlmeier 1999:184, cited in Price 2003:70). Such leadership is characterised by personal and the 'other's' mutual authentic behaviour (Price 2003:70). It fosters congruence between the values of leaders and their followers (Price 2003:70, 185-186; Russel \& Stone 2002). Such leaders' discourse praxes will not necessarily conform to the values that their followers hold (Price 2003:70). They will strive for a cause that transcends individual egoistical needs for the benefit of the larger community (Lipman-Blumen 1996:245, cited in Price 2003:70).

Value-based leadership should thus become morally neutral or even limited in some aspects (Bass \& Steidlmeier 1999; Russel \& Stone 2002). This is so especially when:

7.As with servant leadership, transformational leadership involves personal identification with the leader, shared vision, and going beyond the self-interested exchange of rewards for compliance, resulting in followers being motivated to do more than originally expected' (Hater \& Bass 1988, cited in Kolodinsky et al. 2003:170). 
the gifts of charisma, inspiration, consideration, and intellectual strength are abused for the self-interest of the leader, the effect on followers ceases to be liberating and moral, and becomes instead oppressive and ideological. (Carey 1992:232, cited in Bass \& Steidlmeier 1999)

Abuse of self-interest should be opposed by requiring that leaders act on socialised, as opposed to personalised, power motives (Bass \& Steidlmeier 1999). Internal-authentic and external-authentic leadership responsibilities about the common good for the group, organisation, or society, are thus required (Bass \& Steidlmeier 1999; Dames 2008b). Value-based leadership is morally legitimate only when the values from which leaders act are altruistic in context, content and process and community (Price 2003:70). This counters the tendency to serve 'selfish-altruistic' values by leaders who behave immorally blinded by their own selfinterests. An ethical analysis methodology could help to recognise egoistic-altruistic values and counter immoral actions of leaders.

Ethical analysis should not stop short by merely identifying the immoral and unethical values in leaders. Virtuous character and altruistic values will sometimes conflict with what followers understand to be the morality of practices. 'Leaders must be willing to sacrifice their other-regarding values [demanded by their followers] when generally applicable moral requirements make legitimate demands that they do so' (Price 2003:80). In the next paragraph a new discourse praxis is proposed to deal with the incongruence between leaders themselves and their followers or the 'other'.

\section{Leadership in a new discourse praxis}

Developments in discursive psychology have prompted an analytic hermeneutical and holistic approach to social discourse 'as the central medium for action, psychology and understanding' (Hepburn \& Wiggins 2007:1). A new practical theoretical framework for discourse is required:

Theoretical discourse ... provides a conceptual space for addressing how forms of knowledge function in culture, and how it provides a critical distance from powerful ideological forms of knowledge like psychology. (Parker 2002:10)

Discourse analysis is helpful in this regard. It is synonymous with post-structural exponents who applied discourseoriented critical psychological analysis (Foucault, Derrida \& Lacan, in Parker 2002:10). ${ }^{8}$ Theoretical discourse, or Van Dijk's (1993) critical discourse analysis, offers a critical conceptual space for discerning the way in which hegemonic ideologies and discourse practices should be transformed to foster value-based leadership discourse. According to Hepburn and Wiggins (2007:13), 'Critical Discourse Analysis is a much broader collection of approaches than either conversation analysis or discursive psychology'. It

8. Foucault studied the history of regimes of truth which form psychological subjects in Western culture. Derrida focused on deconstructing the metaphysics of presence which makes psychology unable to comprehend what it makes absent in its theory and practice. Lacan studied the work of repression and the unconscious in language and practice. Lacan studied the work of repression and the unconscious in language
as the subject produces and refuses what is absent; what is other to itself (Parker 2002:10). should also focus on social critique to address the ideologies and discourses that underpin different discourse forms in society. Social practices are, therefore, analysed in terms of how they relate to leaders' orientations and categories of understanding (Hepburn \& Wiggins 2007:13). This leads us to the question how leadership discourse should address hegemonic or immoral practices in everyday life.

\section{Leadership discourse praxis with a critical hermeneutical lens}

The distinction between discourse and communicative action necessitates a functional analysis to expose hegemonic leadership discourse praxes. Communicative action is the interaction that takes place in everyday life, wherein validity claims are more or less naively accepted. Discourse constitutes an unusual form of communication in which the participants subject themselves to the dominance of an argument. The objective is to come to a consensus or an agreement about the (in)validity of problematic claims. Beliefs, norms and values in everyday interaction are thematised and subjected to critique. Discourses may be institutionalised for certain domains, for example practical questions and political or leadership decisions.

Discourse analysis should therefore assist in the analysis of institutionalised language and move beyond mere sentence construction (Mouton 2005:168-170). Discourse analysis studies the semantics of language and employs exploratory and descriptive questions in the analysis of everyday conversations and discourses. It focuses on the rules of discourse in the sense making of contemporary discourse praxes (Parker 2002:125). Discourse analysis is predominantly an inductive study interpreting and making sense of different pieces of discourse; however, most discursive practices have limitations such as being context-dependent or context-bound. Discourse analysis integrates with social psychology and even with faith communication actions, especially in homiletics (Pieterse 2001), because it promotes the value of systematic investigation, instead of asserting the social consequences of the use of different discourse praxes (Abrams \& Hogg 2002:172). The methodology of Van Dijk (1993), in this regard, is an example of critical discourse analysis (Mouton 2005:170). Van Dijk's (1993:259) social and cognitive framework offers a transformational hermeneutical lens for critical discourse analysis. Discourse analysis studies the circumstances surrounding discourse and reflections on them (Abrams \& Hogg 2002:172). Critical discourse analysis (1) examines the process that powerful speakers or groups use to project power in their discourse; and (2) reflects on the discursive structures and strategies that are involved in the process. According to Van Dijk (1993:259), 'Discursive (re)production of power results from social cognitions of the powerful' whilst the situated discourse structures are grounded in social cognitions. We will address the challenge of power reproduction in discourse in terms of contextual social discourse praxes in the next paragraph. 


\section{Segregated discourse structures}

Discourse may become a segregated structure if voices are censored, opinions not heard and perspectives ignored. Moreover, according to Van Dijk (1993:260), 'Blacks or women may thus not only exercise their rights as speakers and opinion givers, but they may also be banished as hearers and contestants of power'. The less powerful are less quoted and less spoken about. Members of less powerful groups, even when present as participants, may more or less be dominated in discourse. A general example is that men may subtly or bluntly exclude women from taking the floor or from choosing specific topics (Van Dijk 1993:260-261). Hegemonic groups may also use denial as another strategy for reproducing their dominance over the powerless 'other'. The notion that all people in a specific society are equal and have equal access to social resources is a typical example of how hegemonic groups may use denial to justify their privileged positions (Van Dijk 1993:263). Hegemonic groups justify inequality through positive self-representation and negative representation of the 'other'. These complementary strategies are also present in white discourse structures about ethnic minorities in everyday conversations, leadership or political discourse, sports broadcasting, textbooks or news reports (Van Dijk 1993:263-264). This brings us to the question how the abovementioned challenges should be addressed.

\section{Liberating the voicelessness of the 'other'}

Contemporary ethicists and reflective practitioners are reclaiming ethics for the multiple existential challenges of our time within diverse contexts (Crotty 2005; Dames 2008b; Van Dijk 1993). The role and meaning of ethics are challenged in a postmodern society by multiple paradigm shifts (from positivism over arbitrary moral preferences to modes of post-empiricism - different dimensions of reasoning and argumentation). These paradigm shifts from theoretical to practical philosophy, from the analysis of things to that of actions, introduce a new critical hermeneutical lens. The shift from subjectivity or consciousness to language or a linguistic turn is even more apparent (cf. Habermas 2001:viii, ix-x; Crotty 2005:143). These shifts have resulted in the reformulation of ethics as a meta-theoretical enterprise (Dallmayr 1991:1)9. Ethics is, thus, crucial in leadership communicative and discourse enactments. Communicative or discourse ethics focus more on social or inter-subjective communicative praxes. Participative communicative and discourse praxes are not individual thought experiments, but social or inter-subjective engagements. As the cognitive ethics of language it is cognitive-rational only in terms of the normative structure of language; namely, the ideal speech or communication community (Crotty 2005:144; Dallmayr 1991:2).

An ideal leadership community of communication is therefore the quintessence of communicative ethics. Communicative ethics is principally not concerned with

9. The positivist privileging of "is" over "ought" was succinctly formulated by Maclntyre in these lines: "Reason is calculative: it can access truths of fact and mathematical relations but nothing more. In the realm of practice it can speak only mathematical relations but nothing more. In the realm of practice it can speak only
of means. About ends it must be silent"' (Hauerwas \& Maclntyre 1983, in Dallmayr 1991:1) the formulation of concrete norms or values, rather its central focus is on the grounding of normativity itself. Grounded normativity works with the rational validation or justification of meta-ethical principles and the specification of appropriate validation procedures, such as critical discourse analysis, to ensure congruence and authenticity in leadership discourse (Dallmayr 1991:3). This brings us to the question: How to realise consensus or congruence between the values of leaders and that of their followers?

\section{Towards value-based leadership discourse}

Communicative ethics provides a comprehensive normative and rationally grounded tool for the development of ethics and normative principles to analyse value-based leadership communication or discourse praxes (Dallmayr 1991:5). Communicative principles inform real-life transactions which envision and presuppose the actions and conditions of an ideal leadership communication community. Ideal forms of communication and social interaction are the ultimate objectives of leadership praxis (Dallmayr 1991:6). However, real-life transactions are not always geared to an ideal communication scenario!

The objective of value-based leadership discourse or communicative ethics should rather focus on the realisation of the other's values as consensual participants in practical discourse. Consensus is not an abstract construct, but a pragmatic principle with a social or public outcome (cf. Russel \& Stone 2002). It aims at impartiality and inclusiveness regarding the interests and perspectives of the 'other'. Leadership discourse ethics is normative only insofar as it claims validity when the 'other' consents to this validity as the participant in a practical discourse (Crotty 2005:144; Dallmayr 1991:8). Altruistic and other regarding values (demanded by followers) should be in congruence - supported by valuebased leadership discourse. This highlights the need for a methodology for value-based leadership discourse.

\section{Value-based leadership discourse methodology}

A critical communicative action theory to construct a methodological discourse framework for leaders is sought (Crotty 2005:42; 149-156; Freire 1972; Habermas 2001). The objective is to develop a socio-political critique for justice, freedom and equity through appropriate leadership dialogue conditions (Crotty 2005:157). Servant leadership and social interaction are key constructs in this regard.

A distinction between servant leadership as an instrumental action and social interaction as a communicative action is drawn; and combined with the dynamics of power and domination (Crotty 2005:142). The notion of systematically distorted communication through a theory of communicative competence is transformed by setting the conditions for the ideal speech situation in pursuit of emancipation (Crotty 2005:142; cf. Dallmayr 1991:9). ${ }^{10}$

10.'The ideal speech situation is one that is free from systematic distortion, allows unimpaired self-presentation by participants, and is characterised by mutuality of unimpaired self-presentation by participants, and is characterised by mutuality of
expectations rather than one-sided norms. In such a situation, discourse is "unrestrained expectations rather than one-sided norms. In such a situation, discourse is "unrestrained
and universal" and enables an "unconstrained consensus" to emerge whereby the idea and universal" and enables an "unconstrained consensus" to emerge where
of truth can be analysed' (Habermas 1970b:370-2 in Crotty 2005:143). 
Crotty (2005:144) employs a broader understanding of communicative action that focuses on moral-practical reasoning (Crotty 2005:146). This focus has a practical and democratic purpose in terms of which political decisions are subjected to the discussion of a reasoning public (Crotty 2005:147). Crotty (2005:147), in this regard, refers to Freire's (1972) pedagogy of the oppressed in challenging power and dominance conditions; ${ }^{11}$ in particular by the ruling leadership elites of our world who possess more responsibilities of knowledge and hold a greater dependence on knowledge responsibilities (Crotty 2005:113). The technical possession, use and control of the expertise knowledge of leadership elites can be both a strength and a vulnerability:

When we look around at the influence and strength of money, of armies, of legal officials, or indeed at the ease with which writers are silenced through censorship, violence and imprisonment, it seems that the word is a fragile blossom. ... Language - not money or force - provides legitimacy. (Saul 1992:8 in Crotty 2005:113-114)

\section{A culture of silence}

Power and dominance over language are measured by leaders' control over or access to discourse. It is a form of social action control and implies the conditions of control over the minds of people. More control over text or context is associated with more influence and results in hegemony. Sampson (2007) refers to 'a struggle of the mind' regarding conditions of control over text and context:

It's the way in which we apply our minds to the information that we have. It's how we engage with the actual realities of our democracy, rather than simply to hear the voices of a vocal minority. It's also to hear the voices of the silent majority. Where do we hear those voices? Do our politicians hear those voices? Do they even begin to hear those voices? (p. 3)

This leads to the question: How the manipulation of power by leaders impacts on their followers? Crotty (2005:154156) ${ }^{12}$ argues that, as a result of a culture of silence, the oppressed are not sufficiently conscious of their situation to change it:

The masses are mute in an oppressed condition; they have no voice. They are excluded from any active role in the transformation of their society and are therefore 'prohibited from being'. (Crotty 2005:155; Freire 1972:30)

The minority does not:

only [not] have a voice, but worse still, they are unaware that they do not have a voice. [T] hey cannot exercise their right to participate consciously in the socio-historical transformation of their society. (Crotty 2005:155; Freire 1972:30; Lange 1972:2, 6)

11.'He wants them to feel that they have the power over their words and can exercise power over them' (Crotty 2005:148-149).

12.'In a culture of silence, the dominated have introjected the cultural myths of the dominators. ... the only approach is the way of dialogue. The oppressed cannot be liberated without their reflective participation in the act of liberation (Freire 1972:41). With regard to faith in human beings, a methodology that is 'dialogical, problem-posing and conscientising' is proposed (Freire 1972:157) "Problematisation is at the same time a "demythicisation". With this demythicisation comes a new view of reality and a founded hope for freedom. It makes possible a conscientised people. They are people emerging from their situation to reflect upon it and cast aside the culture of silence that has held their consciousness submerged' (Crotty 2005:156).
Sampson (2007) accentuates Freire's argument and defines this disposition as a battle of the mind:

We all know that in any society you have a vocal minority and a silent majority. And if you think in the ways it becomes very difficult for the words, for the thoughts, for the ideas of the silent majority to begin to permeate right up to the top. We don't hear it often even, but it remains a challenge. What we are dealing with at the end of the day really is a battle of the mind. (p. 4)

This brings us to the question: How does a vocal minority of leaders control information and influence the perceptions of the silent majority?

\section{Controlling the public mind}

Leaders' control of discourse access represents one of the critical social dimensions of dominance. The exercise of power usually presupposes the control of the mind, involving the influence of knowledge, beliefs, understanding, plans, attitudes, ideologies, norms and values. The control of different modes of knowledge access leads ultimately towards access to the public mind or social cognition (Van Dijk 1993:257). Social cognition refers to cultural and social organisation and representations of society as a whole (Van Dijk 1993:257). Leadership discourse or communication and other forms of action and interaction are viewed by social cognition through social events, social institutions and power relations. Institutionalised discourse, for instance, has reference (Crotty 2005:144). Moreover:

The debate is so much about the rights of the media that we are not looking at the importance of the role of the media. By its very nature the media is not the most accurate commentary of the health of our democracy. (Sampson 2007:4)

Incongruence between altruistic values and access to information lead to the abuse of power. The control of knowledge shapes leaders' interpretation of the world, their discourse and actions. The relevance of critical analysis is, therefore, critical with regard to leadership discourse or communication (Van Dijk 1993:285). Critical discourse analysis is a detailed description, explanation and critique of the ways dominant discourses (indirectly) influence socially shared knowledge, attitudes and ideologies through their role in the development of concrete models (Van Dijk 1993:258-259). An assessment of how specific discourse structures determine specific mental processes, or facilitate the formation of specific social representations, has been put into practice by Barack Obama, the United States of America's first Democratic black presidential candidate. He is an example of how social attitudes can be changed and white leadership elite models decontextualised (Hutchinson 2008).

The Obama example illuminates the relationship between symbolic discourse structures and the structures of social cognition which informs the analytical focus of value-based leaders. Leadership analysis of discursive and cognitive structures are grounded in what Van Dijk (1993:259) refers to as a broader social, political or cultural theory of the 
situations, contexts, institutions, groups and power relations that enable symbolic structures. ${ }^{13}$ In the next paragraph a practical theological leadership praxis will be offered as another example of what Van Dijk describes as a symbolic structure which informs and guides appropriate leadership discourse.

\section{Within a practical theology leadership praxis}

Contemporary practical theology functions within a comprehensive symbolic perspective, especially through cross-disciplinary dialogue. Osmer's (2008:25) crossdisciplinary dialogue encompasses leadership insights or values as a resource for the church's reflection on its life and mission. Such dialogue is characterised by theological and ethical perspectives and contributes to practical wisdom of the whole community - towards an ideal discourse community. Cross-disciplinary dialogue (within comprehensive symbolic perspectives: theology, psychology, linguistics, communication, ethics, business science, etc.) deals with the complexity of leadership discourse (VillaVicencio \& De Gruchy 1994). Osmer (2008:15) refers to the complexities of dialogue as the interconnectedness or the 'web of life' of leadership praxes.

Practical theology interpretation is deeply contextual in terms of leaders' interconnections, relationships and systems. Theology is in essence dialogical, embodied in a Christian hermeneutical community, 'the living [leadership] document', informed through 'a dialogical theory of inspiration' (Mt 19:16-22; Gerkin 1997; Osmer 2008:18; Pieterse 2001:4-5). Humans or leaders are in essence hermeneutical beings (Heidegger in Osmer 2008:21). Theology engenders meaning searching and understanding of the relationship between God, his creation and human beings (Pieterse 2001:5-7).

Practical theology is therefore a study of communicative leadership acts in the service of the gospel within the context of the pre-modern, modern and postmodern society (Firet 1968:125-127; Heitink 1993:154). It is an intentional science of communicative action with the intention to transform praxis. The dialectical role of leaders aims at addressing the bipolar tension between theory and praxis through the hermeneutical approach. Communicative action in the light of theological theory seeks to change existential realities in church contexts or society (Pieterse 2001:9). The intentional praxis of leaders is to construct new theological theories for a new discourse praxis (Pieterse 2001:9). Practical theology studies the praxis of the church, leadership, members and communication in church and society. To engender transformation, practical theology applies, like Crotty (2005) and Van Dijk (1993), Habermas's (2001) communication model based on his ideological critical communication theory to redress power

13.The dialectical relationship between human beings and their concrete historical and cultural reality are instrumental in engendering authentic though-language (Freire
1972:13). Transformation fosters humanisation, but humans can be dehumanised 1972:13). Transformation fosters humanisation, but humans can be dehumanised
in failing to become fully human (Freire 1972:55). 'Such dehumanisation is the characteristic of exploitation, oppression and all other forms of injustice, marking characteristic of exploitation, oppression and all other forms of injustice, marking
both those whose humanity is stolen and those who have stolen it' (Crotty 2005:152). relations. Critical theory applied to leadership praxis fosters justice and righteousness, human dignity and freedom in terms of the communicative actions and values of the kingdom (Pieterse 2001:10; Van der Ven 1998:40).

Osmer's (2008:26) leadership communication model is broad and comprehensive. Leadership as human (symbolic) communication reconfigures the attitudes and behaviour of others in concurrence with shared group goals and needs. Transforming leadership aims at profoundly changing leadership praxes, organisations, systems' identity, mission and cultures (Osmer 2008:177). We concur with Osmer (2008) that practical theology addresses and changes leadership communicative actions in church and society through valuegrounded leadership:

God's sovereign, royal rule takes the form of self-giving love in Christ. The Lord is a servant, and the Servant is the Lord. Power and authority are redefined. A reversal takes place. Power as domination, or power over, becomes power as mutual care and self-giving. Power as seeking one's own advantage becomes power as seeking the good of others and the common good of the community. (p. 191)

\section{Conclusion}

It is clear that we have an existential tension between the voice of the powerful leadership elite and the powerless 'other's' numbness or lack of access to being heard. The effects of dominant leadership discourse dictate public opinion and reproduce, in effect, dominance and inequality. The role of leaders should receive renewed attention, especially in a transforming democracy that represents a society that is growing poorer, with decreasing discourse access. We need a value-based, albeit authentic, spiritual, ethical and transformational leadership, with a renewed critical consciousness for moral and ethical discourse and communication action and reflection.

Leadership that is spiritual, authentic, ethical and transformational, and which manifests itself though ethical discourse, fosters authentic relationships and transforms hegemonic leadership practices.

\section{Acknowledgements Competing interests}

The author declares that he has no financial or personal relationship(s) that may have inappropriately influenced him in writing this article.

\section{References}

Abrams, D. \& Hogg, M.A., 2002, 'The context of discourse: Let's not throw out the baby with the bathwater', in I. Parker (ed.), Critical discursive psychology, p. 172, Palgrave Macmillan, Basingstoke.

Avolio, B.J., Walumbwa, F.O. \& Weber, T.J., 2009, 'Leadership: Current theories. Research and future directions', Annual Review of Psychology 60, 421-449. http:// dx.doi.org/10.1146/annurev.psych.60.110707.163621

Bass, B.M., 1985, Leadership and performance beyond expectations, Free Press, New York.

Bass, B.M. \& Avolio B.J. (eds.), 1994, Improving organizational effectiveness through transformational leadership, Sage Publications, Thousand Oaks.

Bass, B.M. \& Steidlmeier, P., 1999, 'Ethics, character, and authentic transformational leadership behaviour', The Leadership Quarterly 10(2), viewed 25 March 2009, from http://web.ebscohost.com.ez.sun.ac.za/ehost/ 
Crossman, J., 2010, 'Conceptualising spiritual leadership in secular organizational contexts and its relation to transformational, servant and environmental leadership', Leadership \& Organisational Development Journal 31(7), 596-608. leadership', Leadership \& Organisational Develop
http://dx.doi.org/10.1108/01437731011079646

Crotty, M., 2005, The foundations of social research: Meaning and perspective in the research process, Sage, London.

Dallmayr, F., 1991, 'Introduction', in S. Benhabib \& F. Dallmayr (eds.), The communicative ethics controversy, pp. 1-9, MIT Press, London.

Dames, G., 2008a, 'Ethical leadership in and through labour, business and politics', Dutch Reformed Theological Journal 49(3/4), 100-112.

Dames, G., 2008b, 'The ethical leadership project: Its role as a key contributor for a morally transformed society', Dutch Reformed Theological Journal 50, 36-49.

Dobbs, R., 2010, Transformational leadership: A blueprint for real organisational change, Parkhurst Brothers, Chicago.

Doohan, L., 2007, Spiritual leadership: The quest for integrity, Paulist Press, New York.

Firet, J., 1968, Het agogisch moment in het pastoraal optreden, Kok, Kampen.

Freire, P., 1972, Pedagogy van de onderdrukten, Kok, Kampen.

Gall, T.L., Mallette, J. \& Guirguis-Younger, M., 2011, 'Spirituality and religiousness: A diversity of definitions', Journal of Spirituality in Mental Health 13(3), 158-181. $\mathrm{http} / / / \mathrm{dx}$.doi.org/10.1080/19349637.2011.593404

Gerkin, C.V., 1997, An introduction to pastoral care, Abingdon Press, Nashville.

Giacalone, R.A. \& Jurkiewicz, C.L. (eds.), 2003, Handbook of workplace spirituality and organizational performance, ME Sharpe, New York.

Granberg-Michaelson, W., 2004, Leadership from inside out: Spirituality and organizational change, Crossroad, New York.

Habermas, J., 2001, On the pragmatics of social interaction: Preliminary studies in the theory of communicative action, transl. B. Fultner, MIT Press, Cambridge.

Heitink, G., 1993, Praktische theologie: Geschiedenis, theorie, handelingsvelden, Kok Kampen. PMid:8333911

Hepburn, A. \& Wiggins, S. (eds.), 2007, Discursive research in practice: New approaches to psychology and interaction, Cambridge University Press, Cambridge. http:// dx.doi.org/10.1017/СВ09780511611216

Hess, E.D. \& Cameron, K.S., 2006, Leading with values: Positivity, virtue, and high performance, Cambridge University Press, Cambridge. http://dx.doi.org/10.1017/ CBO9780511753770

Hutchinson, E.O., 2008, The ethnic presidency: How race decides the race to the White House, Middle Passage Press, viewed 16 May 2013, from http://www. americanchronicle.com/articles/view/53011

Keifert, P., 2006, A missional journey of spiritual discovery: We are here now. A new missional era, Allelon Publishing Co., Eagle.

Kolodinsky, R.W., Bowen, M.G. \& Ferris, G.R., 2003, 'Embracing workplace spirituality and managing organizational politics: Servant leadership and political skill fo volatile times', in R.A. Giacalone \& C.L. Jurkiewicz (eds.), Handbook of workplace spirituality and organizational performance, pp. 169-170, ME Sharpe, New York.
Lange, E., 1972, 'Introduction', in P. Freire (ed.), Pedagogy van de onderdrukten, pp. 2, 6, Kok, Kampen

Mandela, N.R., 1995, Long walk to freedom, Abacus, London.

Mouton, J., 2005, How to succeed in your master's and doctoral studies: A South African guide and resource book, 5th edn., Van Schaik, Pretoria.

Osmer, R.R., 2008, Practical theology: An introduction, Eerdmans, Grand Rapids.

Parboteeah, K.P. \& Cullen, J.B., 2003, 'Ethical consumption and business: A pragmatic perspective', in R.A. Giacalone \& C.L. Jurkiewicz (eds.), Handbook of workplace spirituality and organizational performance pp. 138, 149-150, ME Sharpe, New York.

Parker, I., 2002, Critical discursive psychology, Palgrave Macmillan, Basingstoke. $\mathrm{http}: / / d x$. doi.org/10.1057/9781403914651

Pieterse, H.J.C., 2001, Preaching in a context of poverty, UNISA, Pretoria. PMCid:PMC64867

Price, T.L., 2003 'The ethics of authentic transformational leadership', The Leadership Quarterly 14, 67-81. http://dx.doi.org/10.1016/S1048-9843(02)00187-X

Rensburg, A., 2002, 'Archbishop Desmond Tutu as moral sage and servant leader: A compassionate zealot', Verbum et Ecclesia 23(3), 746-761. http://dx.doi. org/10.4102/ve.v23i3.1237

Rowan, J., 2001, Ordinary ecstasy: The dialectics of humanistic psychology, 3rd edn., Brunner-Routledge, East Sussex.

Roxburgh, A.J., 2005, The sky is falling!?! Leaders lost in transition, ACl, Eagle.

Russel, F.R., 2001, 'The role of values in servant leadership', Leadership \& Organization Development Journal 22(2), 76-83. http://dx.doi. org/10.1108/01437730110382631

Russel, F.R. \& Stone, A.G.A., 2002, 'Review of servant leadership attributes: Developing a practical model', Leadership \& Organization Development Journal 23(3), 145157. http://dx.doi.org/10.1108/01437730210424

Sampson, C., 2007, 'The challenge of moral renewal in politics', paper presented at the Ethical Leadership Project conference, University of the Western Cape, Bellville, 6-7th September.

Snyder, C.R. \& Lopez, S.J. (eds.), 2002, Handbook of positive psychology, Oxford University Press, New York.

Strock, J.M., 2010, Serve to lead: Your transformational 21st century leadership system. Serve to Lead Press, Arizona.

Van der Ven, J.A., 1998, Formation of the moral self, Eerdmans, Grand Rapids.

Van Dijk, T.A., 1993, 'Principles of critical discourse analysis', Discourse \& Society 4(2), 249-283. http://dx.doi.org/10.1177/0957926593004002006

Van Eeden, R., Cilliers, F. \& Van Deventer, V., 2008, 'Leadership styles and associated personality traits: Support for the conceptualisation of transactional and transformational leadership', South African Journal of Psychology 38(2), 253-267. http://dx.doi.org/10.1177/008124630803800201

Villa-Vicencio, C, \& De Gruchy, J., 1994, Doing ethics in context: South African perspectives. Theology and praxis, vol. 2, Orbis Books, New York.

Wallis, J., 2004, 'About leadership', in W. Granberg-Michaelson (ed.), Leadership from inside out: Spirituality and organizational change, pp. 9-11, Crossroad, New York.

Yukl, G., 2006, Leadership in organizations, 6th edn., Pearson Prentice Hall, Upper Saddle River. 